\title{
Application of SWAT to Assess the Effects of Land Use Change in the Murchison Bay Catchment in Uganda
}

\author{
Listowel Abugri Anaba1, Noble Banadda1, Nicholas Kiggundu¹, Joshua Wanyama1, Bernie Engel2, \\ Daniel Moriasi $^{3}$
}

${ }^{1}$ Department of Agricultural and Biosystems Engineering, Makerere University, Kampala, Uganda

${ }^{2}$ Department of Agricultural and Biological Engineering, Purdue University, West Lafayette, IN, USA

${ }^{3}$ USDA-ARS Grazing Lands Research Laboratory, El Reno, OK, USA

Email:kiggundu@caes.mak.ac.ug

How to cite this paper: Anaba, L.A., Banadda, N., Kiggundu, N., Wanyama, J., Engel, B. and Moriasi, D. (2017) Application of SWAT to Assess the Effects of Land Use Change in the Murchison Bay Catchment in Uganda. Computational Water, Energy, and Environmental Engineering, 6, 24-40. http://dx.doi.org/10.4236/cweee.2017.61003

Received: November 1, 2016

Accepted: December 17, 2016

Published: December 20, 2016

Copyright (c) 2017 by authors and Scientific Research Publishing Inc. This work is licensed under the Creative Commons Attribution International License (CC BY 4.0).

http://creativecommons.org/licenses/by/4.0/

\begin{abstract}
The Soil and Water Assessment Tool (SWAT) is a versatile model presently used worldwide to evaluate water quality and hydrological concerns under varying land use and environmental conditions. In this study, SWAT was used to simulate streamflow and to estimate sediment yield and nutrients loss from the Murchison Bay catchment as a result of land use changes. The SWAT model was calibrated and validated for streamflow for extended periods. The Sequential Uncertainty Fitting (SUFI-2) global sensitivity method within SWAT Calibration and Uncertainty Procedures (SWAT-CUP) was used to identify the most sensitive streamflow parameters. The model satisfactorily simulated stream discharge from the catchment. The model performance was determined with different statistical methods. The results showed a satisfactory model streamflow simulation performance. The results of runoff and average upland sediment yield estimated from the catchment showed that, both have increased over the period of study. The increasing rate of runoff can lead to severe and frequent flooding, lower water quality and reduce crop yield in the catchment. Therefore, comprehensive water management steps should be taken to reduce surface runoff in the catchment. This is the first time the SWAT model has been used in the Murchison Bay catchment. The results showed that, if all uncertainties are minimised, a well calibrated SWAT model can generate reasonable hydrologic simulation results in relation to land use, which is useful to water and environmental resources managers and policy and decision makers.
\end{abstract}

\section{Keywords}

Land Use-Cover, Murchison Bay Catchment, SWAT, Calibration, Validation, Streamflow 


\section{Introduction}

Land use change can lead to undesirable effects on ecosystems [1]. Land use and land cover changes are significant causes of water, soil and air pollution [2], which negatively impacts the health of rivers within catchments. The effects of land use changes can be grouped into hydrologic, socio-economic, ecological and environmental [1]. Most river basins have undergone massive change over the past years due to various land use activities [3]. According to [4], land use and land cover transformations could lead to change in flow pattern of rivers due to temporal changes in the distribution of runoff.

Land use and land cover changes are very common in developing countries whose economies are mainly dependent on agriculture and with rapid human population growth [5]. Vegetation removal to prepare land for agriculture leaves soil susceptible to massive increase in soil erosion by wind and water. This reduces the fertility of the soil rendering it unsuitable for agricultural purposes, as well as transport large volumes of nitrogen, phosphorus, and sediments to streams which can lead to various negative impacts such as increased sedimentation, turbidity, eutrophication and coastal hypoxia of wetlands and rivers. The use of agrochemicals such as herbicides, pesticides, and inorganic fertilizers in modern-day agriculture has hugely contributed to increased levels of pollution in surface water bodies as well as contamination of groundwater through runoff and by way of leaching. This pollution in most cases is toxic to aquatic life [2] and humans. These impacts not only affect the immediate area but their effects can extend to distant regions [3].

The Murchison Bay catchment in Uganda, which is a major contributor of water for the people in the capital city Kampala, has experienced a lot of land use-land cover transformations over the years. The change of land use from its natural vegetation has caused environmental degradation resulting from inadequate facilities for sewage and sanitation, poor drainage system, and increased industrial pollution and urban agriculture [6]. For instance, different studies [7]-[13] have reported the rising levels of pollution and its increasing impact as a result of expansion of Kampala, wetland encroachment, poor agricultural practices and deforestation in parts of this catchment. Agricultural production in the immediate environs of Kampala has led to rapid devastation of green belts causing deforestation and has led to reduced soil water retention capacity and accelerated erosion [6]. Indiscriminate drainage of wetlands in the city environs for cultivation has also affected the water table. Drainage of wetlands has led them to lose their function to control floods, filter effluents and purification of waters before been discharged into Lake Victoria. As a result of these changes, the cost of treating water has become the major bottleneck to National Water and Sewerage Corporation (NWSC), an institution in charge of treating and supplying water to Kampala City inhabitants [8].

According to Li et al. [14], management of water resources and land use patterns are inherently linked. At the catchment level, the type of land use, such as agricultural production, forests, human settlements, industrial and commercial centers, influences the quantity and quality of available water. Continuous monitoring of water quality parameters is expensive, time consuming, and at times difficult [15]. A number of hydrologic and water quality simulations models have been developed to examine the impact 
of different land use practices on water resources. The results of these models are used to help policy and decision makers determine cost-effective land management and conservation practices to sustain water resources for current and future populations under a changing climate [16] [17] [18]. One of such models is the Soil and Water Assessment Tool (SWAT).

SWAT is a river basin scale and continuous time model that operates on daily time step. This model is designed to quantify and predict the impact of land management practices over long periods on water, sediment and agricultural chemical yields in large complex watersheds with varying soils, land use and management conditions [19] [20] [21]. Expanded routing and pollutant transport abilities including reservoir, point source, pond, wetland, septic tank effects and enhanced sediment routing routines have also been incorporated into the SWAT model. SWAT is a versatile model currently used worldwide to evaluate water quality and hydrological concerns in a number of varying watershed scales and environmental conditions [22] for abreast policy decision making and effective watershed management. Details of SWAT are in [21] [23].

Assessing the impacts of land use and land cover changes on hydrology forms the foundation for managing watershed and restoring its ecology [24]. In this study, the SWAT model was used to simulate streamflow and also to estimate the amount of sediment yield and nutrients loss from the Murchison Bay Catchment as a result of land use-land cover changes.

\section{Materials and Methods}

\subsection{Study Area}

The Murchison Bay is an extension of Lake Victoria situated in the south-east of Kampala which lies between latitudes $00^{\circ} 10^{\prime} 00^{\prime \prime} \mathrm{N}-00^{\circ} 30^{\prime} 00^{\prime \prime} \mathrm{N}$ and longitudes $32^{\circ} 35^{\prime} 00^{\prime} \mathrm{E}$ $32^{\circ} 50^{\prime} 00^{\prime \prime} \mathrm{E}$ with average elevation of $1224 \mathrm{~m}$ above sea level. The Bay which is divided into Inner and Outer Bay covers an area of about $60 \mathrm{~km}^{2}$. The Inner Murchison Bay is comparatively a semi-enclosed small water body with an area of $18.4 \mathrm{~km}^{2}$ and length of $5.6 \mathrm{~km}$ off the main part of Lake Victoria. The Murchison Bay watershed covers an average combined catchment area of $282 \mathrm{~km}^{2}$ which consists of about $20 \%$ swamps and $80 \%$ upland [7] [10] with the largest catchment drainage inlet being the Nakivubo channel which passes through Kampala City. This study covers the largest watershed of the Murchison Bay that drains through the Nakivubo Channel (Figure 1). It covers an area of about $40.9 \mathrm{~km}^{2}$. The Nakivubo channel runs from the central populated Kampala district passing through slums, industrial settlements and markets before discharging its water to the Lake Victoria at Murchison Bay. The water in the channel is a mixture of secondary effluents from NWSC sewage treatment at Bugolobi within Kampala city and heavily polluted untreated wastewater from other parts of the city. There used to be a predominant papyrus wetland filtration system but it has been drained and turned into agricultural land or developed for commercial, industrial or residential purposes.

The catchment is within the equatorial belt, and has a moist sub-humid climate. It receives a bi-seasonal rainfall in the periods of March to May and September to November [25]. Mean monthly precipitation ranges from $24 \mathrm{~mm}$ in January to about 154 


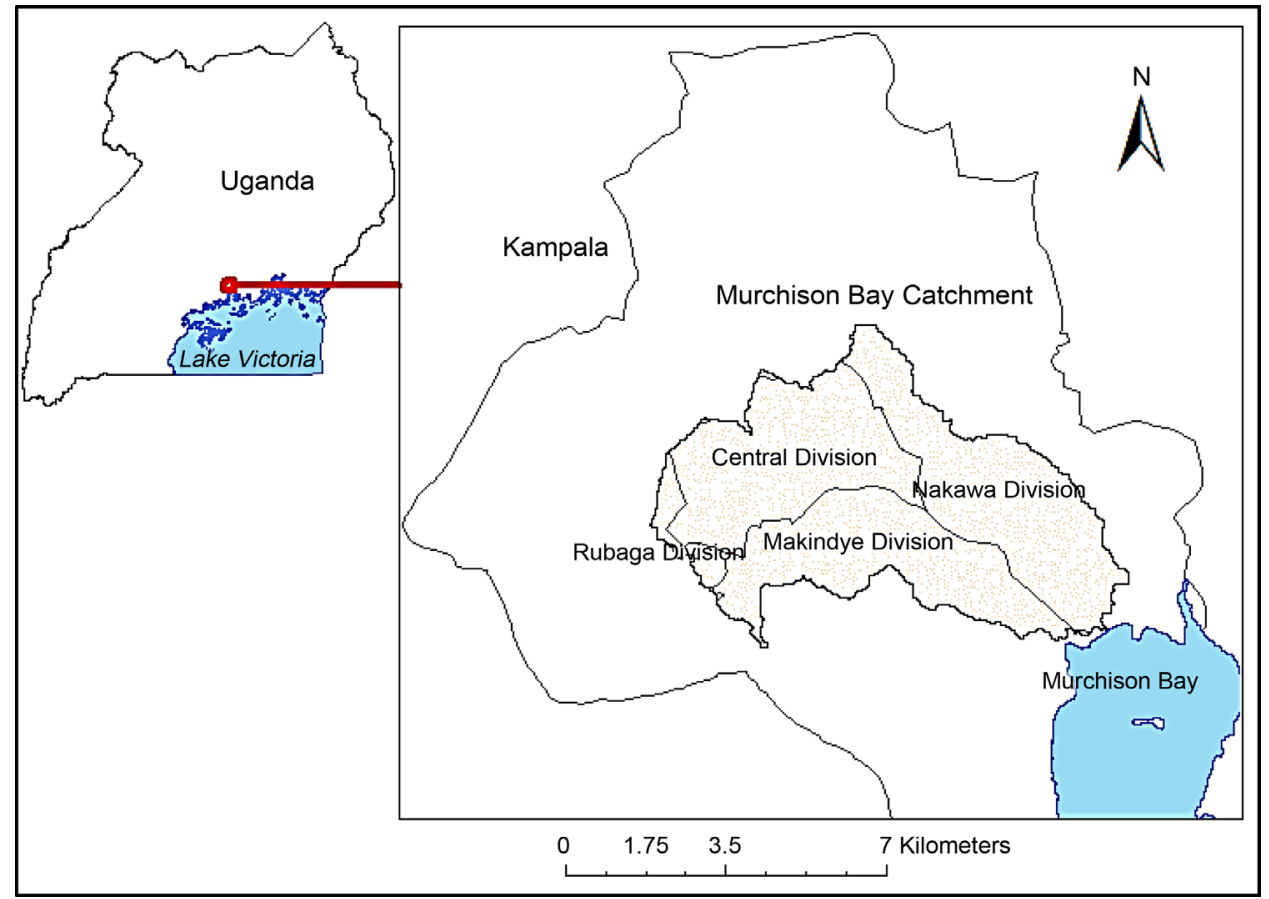

Figure 1. Map of Uganda showing the Murchison Bay Watershed.

$\mathrm{mm}$ in October with mean precipitation of about $1293 \mathrm{~mm} /$ year.

The soils of the Nakivubo swamp area are alluvial and lacustrine sands, silts, and clays overlying granite gneisses. Alluvial soils within the swamp range from semi-liquid organic material in the very upper layers of the emergent vegetation zones, through reddish ferruginous loams to clays [25].

\subsection{Maintaining the Integrity of the Specifications}

The input data used in the study included the Digital Elevation Model (DEM) of Central Uganda, land use-cover map of the Murchison Bay catchment, soil and hydrometeorological data of the study area.

\subsubsection{Digital Elevation Model (DEM)}

A DEM for Central Region of Uganda at a resolution of 1 arc second $(30 \mathrm{~m} \times 30 \mathrm{~m})$ was retrieved from the United States Geological Surveys (USGS) website

(http://gdex.cr.usgs.gov/gdex/). The DEM was used for automatic delineation of the catchment and also to define the stream network and determine sub-basin parameters such as slope [26].

\subsubsection{Land Use and Land Cover Data}

Land use cover maps of 1995 and 2003 were used in this study. These were obtained by visual interpretation of remotely sensed images retrieved from USGS Landsat ETM/TM satellites (http://www.earthexplorer.usgs.gov/) in Path 171 and Row 60 at a spatial resolution of $30 \mathrm{~m}$. The images were classified into five land use-cover types in accordance to Anderson et al. [27] Level I generalized classification system using maximum likelihood supervised classification tool in ArcGIS. These are built-up land, wetland, forestland, agricultural land and open water bodies. Table 1 shows the characteristics of 
land use and land cover in the Murchison Bay catchment.

The major land use and land covers in 1995 were agricultural land (32.42\%), forestland (31.15\%) and built-up land (26.53\%). However, by 2003, built-up land became the most dominated land cover followed by agricultural land while forest land drastically declined. Figure 2 shows the various land use-land covers identified in the Murchison Bay catchment. The main cause of these changes can be attributed to rapid population growth around the catchment which increased by close to 50\% between 1991 and 2002 [28]. According to [10], the rapid growth of Kampala is taking place at the expense of the environment which is highly correlated to the pollution level observed in the Lake Victoria.

\subsubsection{Soil Data}

The soil map was obtained from Land and Water Resource, FAO soil database [29] and the description of the soils from [30]. The dominant soil associations in the Murchison Bay catchment are acric ferrasols, orthic ferrasols and dystrics gleysols. The soil physical and chemical properties included were texture, soil hydrologic groups, maximum

Table 1. Characteristics of land use and land covers in the Murchison Bay catchment.

\begin{tabular}{ccccc}
\hline \multirow{2}{*}{ Land use/cover } & \multicolumn{2}{c}{1995} & \multicolumn{2}{c}{2003} \\
\cline { 2 - 5 } & Area (ha) & $\%$ & Area (ha) & $\%$ \\
\hline Water bodies & 9.00 & 0.22 & 10.62 & 0.26 \\
Agricultural land & 1326.24 & 32.42 & 1502.43 & 36.73 \\
Forest land & 1274.23 & 31.15 & 568.81 & 13.91 \\
Wetland & 395.50 & 9.67 & 409.62 & 10.01 \\
Built-up land & 1085.34 & 26.53 & 1598.81 & 39.09 \\
Total & 4090.30 & 100.00 & $\mathbf{4 0 9 0 . 3 0}$ & 100.00 \\
\hline
\end{tabular}

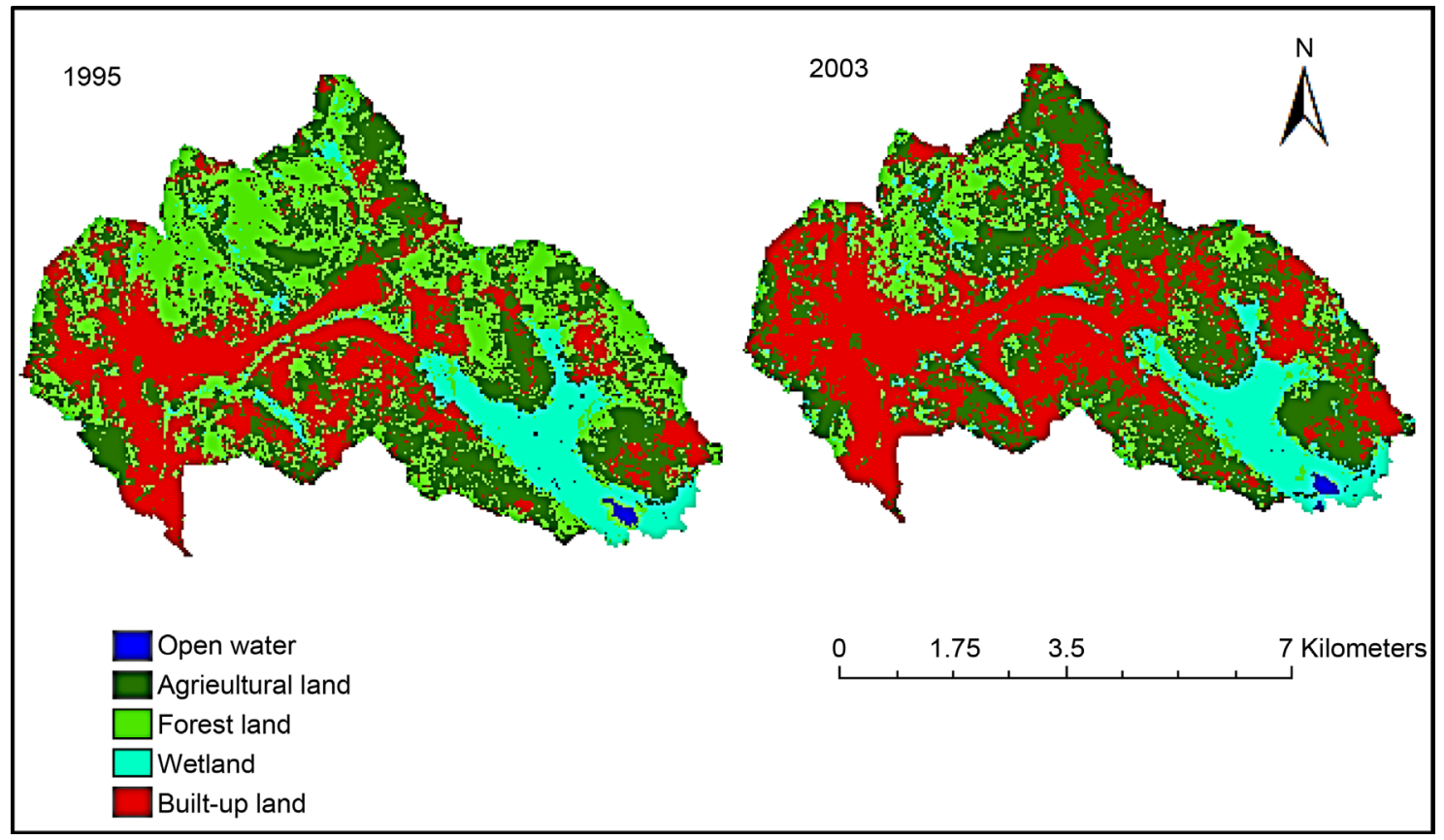

Figure 2. Land use and land cover classified map of the Murchison Bay Catchment. 
rooting depth, fraction of porosity, moist bulk density, available water capacity, saturated hydraulic conductivity, organic carbon content, electrical conductivity, USLE equation soil erodibility factor, sand, silt and rock fragment contents.

\subsubsection{Hydro-Meteorological Data}

Hydrological simulation with the SWAT model requires weather data consisting of precipitation, maximum and minimum temperature, relative humidity, solar radiation and wind speed. These parameters were obtained from the National Centres for Environmental Prediction (NCEP) (http://globalweather.tamu.edu/) and NASA agro-climatology (http://power.larc.nasa.gov/cgi-bin/cgiwrap/solar/agro.cgi) for the period of 1995 to 2010. The weather data was collected from three stations outside and one station within the study area. Stream discharge data was obtained from the Directorate of Water Resource Management (DWRM) under Uganda's Ministry of Water and Environment (MWE) at Entebbe. There is only one stream flow gauge in the Murchison Bay catchment located at the Railway Bridge culvert which is very close to the outlet of the delineated catchment at $32.63^{\circ} \mathrm{E}$ and $0.30^{\circ} \mathrm{N}$. The observed stream flow data for the period from 1997 to 2007 was used for calibration and validation of the model, however, there were data gaps.

\subsection{The SWAT Model Setup}

The model uses readily available input data such as Digital Elevation Model (DEM), land use data, soil data and climatic data as described in Section 2.2. In this study, modelling of the hydrological process was carried out using the extension of SWAT for ArcGIS software called ArcSWAT [31].

ArcSWATv2012.10.1.18 was downloaded from the website for the model (http://swat.tamu.edu/software/arcswat/) and installed in ArcGISv10.1. In the model setup, the first step was to delineate the catchment using the DEM into several connected sub-basins. The sub-basins were further divided into smaller units called hydrologic response units (HRUs). HRUs are lumped land areas within the sub-basin that are comprised of unique land cover, soil, slope and management combinations [21]. A total of 23 sub-basins and 247 HRUs were created. The HRUs were created by defining the thresholds of land use over sub-basin area at 5\%, soil class over land use area at $5 \%$ and slope class over soil area at 5\% using the multiple HRUs definition. The model was run on daily time step for a period of 16 years from 1995 to 2010 with a warm up period of two years.

\subsection{Sensitivity Analysis}

Sensitivity analysis was performed to choose the most sensitive flow parameters [32] [33] [34] [35] that influence the catchment represented by SWAT to be used for calibration. This was achieved using the global sensitivity approach in semi-automated Sequential Uncertainty Fitting (SUFI2) algorithm. The global sensitivity analysis method takes into consideration, the sensitivity of one parameter relative to the other in order to give their statistical significances [36]. The t-statistics and p-values of the parameters were used to rank to the different parameters considered to influence flow and the final selection done based on the significance of the ranked values. Table 2 shows stream 
Table 2. Sensitivity analysis parameters.

\begin{tabular}{cc}
\hline Parameters & Definition \\
\hline ALPHA_BF & Base-flow alpha factor (days) \\
ALPHA_BNK & Base-flow alpha factor for bank storage (dimensionless) \\
CH_K2 & Effective hydraulic conductivity in main channel alluvium (mm/h) \\
CH_N2 & Manning's " $n$ " value for the main channel \\
CN2 & SCS runoff curve number (dimensionless) \\
ESCO & Soil evaporation compensation factor (dimensionless) \\
GW_DELAY & Groundwater delay (days) \\
GW_REVAP & Groundwater "revap" coefficient (dimensionless) \\
GWQMN & Threshold depth of water in the shallow aquifer required for return flow to occur (mm) \\
RCHRG_DP & Deep aquifer percolation fraction (dimensionless) \\
REVAPMN & Threshold depth of water in the shallow aquifer for "revap" to occur $(\mathrm{mm})$ \\
SOL_AWC & Available water capacity of the soil layer (mm $\mathrm{H}_{2} \mathrm{O} / \mathrm{mm}$ soil) \\
SOL_BD & Moist bulk density (Mg/m $\left.{ }^{3}\right)$ \\
SOL_K & Saturated hydraulic conductivity (mm/h) \\
SOL_Z & Depth of soil (mm) \\
SURLAG & Surface runoff lag coefficient $($ dimensionless)
\end{tabular}

flow parameters that were tested for their sensitivity. These are useful in estimating the amount of flow from a catchment [37].

\subsection{Calibration and Validation of the Model}

Calibration was accomplished by comparing the output of the SWAT model with the observed data at the same conditions [19] [38]. For calibration and validation, the semi-automated Sequential Uncertainty Fitting (SUFI-2) calibration method within the SWAT Calibration and Uncertainty Procedures (SWAT-CUP) was used. SWAT-CUP version 5.1.6.2 was used. SWAT-CUP [16] is a stand-alone calibration program developed for SWAT that operates on Latin Hypercupe sampling procedures. Due to lack of observed data for sediment and nutrients, the model was calibrated and validated only for streamflow. The model was calibrated with observed daily discharge data for the period of 1997 to 2002 and validated for the period of 2004 to 2008 since there was no observed data for 2003. Though, there were gaps in the observed data, the challenge was addressed by writing it in a format suggested by [36] that SWAT-CUP tool can read.

\subsection{Evaluation of Model Performance}

To evaluate performance of the model during calibration and validation, statistical measures as well as graphical representations at daily time step were used. This was employed to confirm the relationship between simulated or predicted values and observed values [1] and to verify the robustness of the model [37]. Four statistical measures were employed. They are the coefficient of determination $\left(R^{2}\right)$, the Nash-Sutcliffe efficiency (NSE), the percent bias (PBIAS) and the ratio of mean squared error to the standard deviation of the measured data (RSR) [26] [37] [39]. Equations (1)-(4) were 
used to determine NSE, PBIAS, RSR and $R^{2}$, respectively. Other details of these measures such as their utility and satisfactory range of values are explained by Moriasi et al. [40].

$$
\begin{gathered}
N S E=1-\frac{\sum_{i=1}^{n}\left(O_{i}-S_{i}\right)^{2}}{\sum_{i=1}^{n}\left(O_{i}-\bar{O}\right)^{2}} \\
\text { PBIAS }=\frac{\sum_{i=1}^{n}\left(O_{i}-S_{i}\right) * 100}{\sum_{i=1}^{n}\left(O_{i}\right)} \\
R S R=\frac{\sqrt{\sum_{i=1}^{n}\left(O_{i}-S_{i}\right)^{2}}}{\sqrt{\sum_{i=1}^{n}\left(O_{i}-\bar{O}\right)^{2}}} \\
R^{2}=\frac{\left[\sum_{i=1}^{n}\left(O_{i}-\bar{O}\right)\left(S_{i}-\bar{S}\right)\right]^{2}}{\sum_{i=1}^{n}\left(O_{i}-\bar{O}\right)^{2} * \sum_{i=1}^{n}\left(S_{i}-\bar{S}\right)^{2}}
\end{gathered}
$$

where $O_{i}$ is the observed daily discharge, $S_{i}$ is the simulated daily discharge, $\bar{O}$ is the average measured discharge, $\bar{S}$ is the average simulated discharge and $n$ is the number of observations.

\section{Results and Discussion}

\subsection{Sensitivity Analysis of Stream Flow Parameters Results}

The global sensitivity analysis of 16 flow parameters (Table 2) showed that, only seven were very sensitive to flow. The rankings of the flow parameters are presented in Table 3 while the fitted values for the most sensitive parameters are indicated in Table 4 . The most sensitive parameter was the SCS runoff curve number (CN2). The curve number estimates runoff based on the relationship between precipitation, hydrologic soil group and land uses. Other researchers [41] [42] [43] [44] have also found the SCS curve number to be the most sensitive streamflow parameter in modelling hydrology in their studies. The other sensitive parameters included the Manning's $n$ value for the main channel (CH_N2), effective hydraulic conductivity in the main channel alluvium ( $\left.\mathrm{CH} \_\mathrm{K} 2\right)$ and groundwater delay time (GW_DELAY), baseflow alpha factor (ALPHA_BF), groundwater "revap" coefficient and the soil evaporation compensation factor (ESCO). Although, the rest of the parameters were found not to be sensitive to flow in the catchment as their p-values were greater than 5\%, other studies [37] [39] [45] [46] [47] have found some of them to be sensitive in their studies. This is expected as conditions such as land use and land covers, soil characteristics and climatic factors vary from one catchment to the other.

\subsection{SWAT Model Calibration and Validation Results}

The graphical results of the model streamflow simulation performance during the 
Table 3. Sensitivity rankings of streamflow parameters in the Murchison Bay catchment.

\begin{tabular}{cccc}
\hline Parameter name & t-stat & p-value & Ranking \\
\hline CN2 & -5.902 & 0.000 & 1 \\
CH_N2 & 5.828 & 0.000 & 2 \\
CH_K2 & 4.857 & 0.000 & 3 \\
GW_DELAY & 3.251 & 0.002 & 4 \\
ALPHA_BF & -2.575 & 0.012 & 5 \\
GW_REVAP & -2.295 & 0.024 & 6 \\
ESCO & -2.083 & 0.040 & 7 \\
SOL_K & 1.344 & 0.182 & 8 \\
ALPHA_BNK & 0.758 & 0.451 & 9 \\
SOL_BD & 0.682 & 0.497 & 10 \\
SOL_AWC & 0.681 & 0.497 & 11 \\
SOL_Z & 0.654 & 0.515 & 12 \\
SURLAG & -0.615 & 0.540 & 13 \\
GWQMN & 0.489 & 0.626 & 14 \\
RCHRG_DP & -0.400 & 0.690 & 15 \\
REVAPMN & -0.365 & 0.716 & 16 \\
\hline
\end{tabular}

Table 4. List of sensitive parameters and their calibrated values.

\begin{tabular}{cccc}
\hline Parameter name & Fitted value & Minimum & Maximum \\
\hline r_CN2.mgt & 0.02 & 35 & 98 \\
v_CH_N2.rte & 0.12 & -0.01 & 0.5 \\
v_CH_K2.rte & 165 & -0.01 & 500 \\
v_GW_DELAY.gw & 75.11 & 0 & 500 \\
v_ALPHA_BF.gw & 0.57 & 0 & 1 \\
v_GW_REVAP.gw & 0.11 & 0.02 & 0.2 \\
v_ESCO.hru & 1 & 0 & 1 \\
\hline
\end{tabular}

The extension (e.g., .mgt, .rte) refers to the SWAT input file where the parameter occurs. The qualifier (r__ ) refers to relative change in the parameter where the value from the SWAT database is multiplied by 1 plus a factor in the given range, while the qualifier ( $\mathrm{v}_{-}$) refers to the substitution of a parameter by a value from the given range.

calibration and validation periods are shown in Figures 3-6. The year 2003 was not incorporated in the validation period since there were no recorded observed daily discharges in that year. In general, graphical results during calibration (Figure 3 and Figure 5) and validation (Figure 4 and Figure 6) indicated adequate calibration and validation over the range of streamflow discharge, although the calibration results showed a better match than the validation results. Statistical model streamflow discharge simulation performance results during both calibration and validation periods are presented in Table 5. Generally, the statistical results showed a satisfactory performance of the model [40]. Just as with the graphical results, the model simulated streamflow discharge better during the calibration period than the validation period. The relatively low statistical measures during the validation can be attributed to the quality of the observed data 


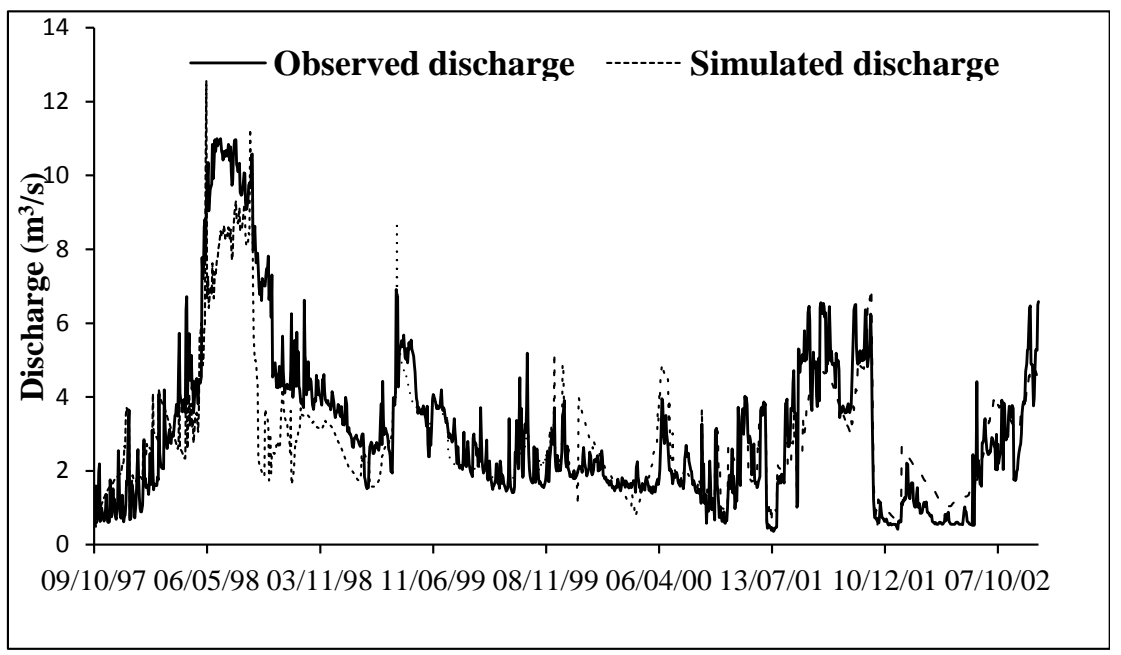

Figure 3. Observed and simulated daily discharge for the Murchison Bay catchment during calibration (1997-2002).

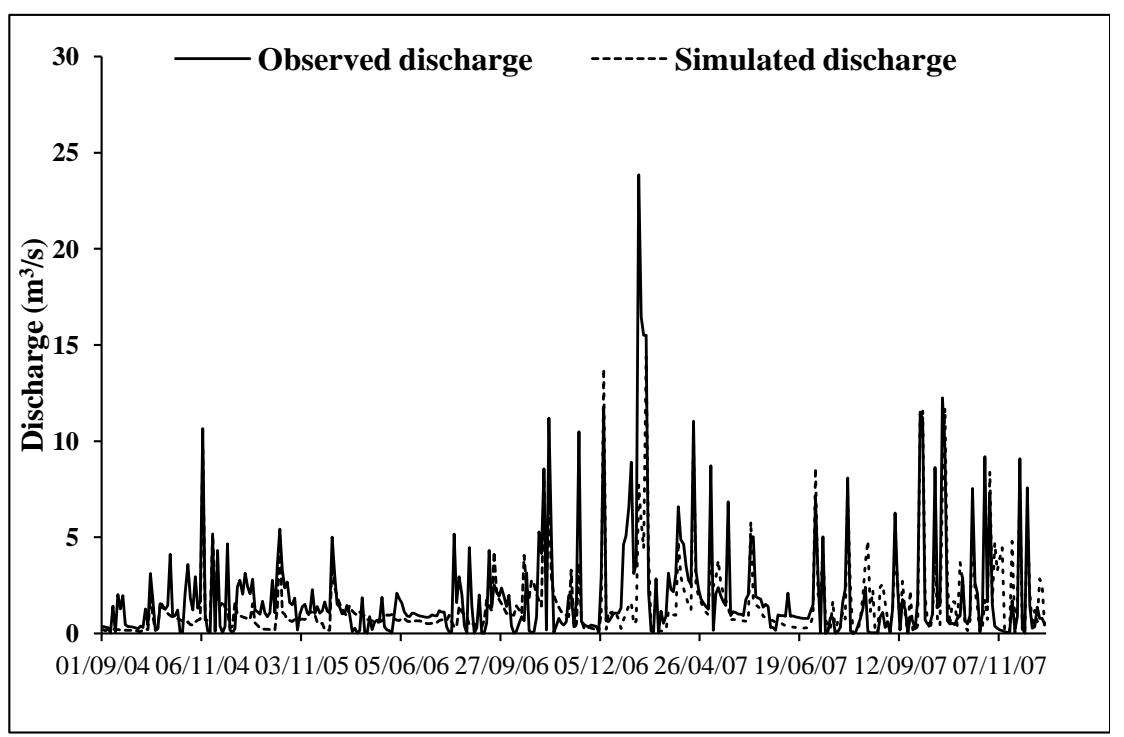

Figure 4. Observed and simulated daily discharge for the Murchison Bay catchment during the validation period (2004-2007).

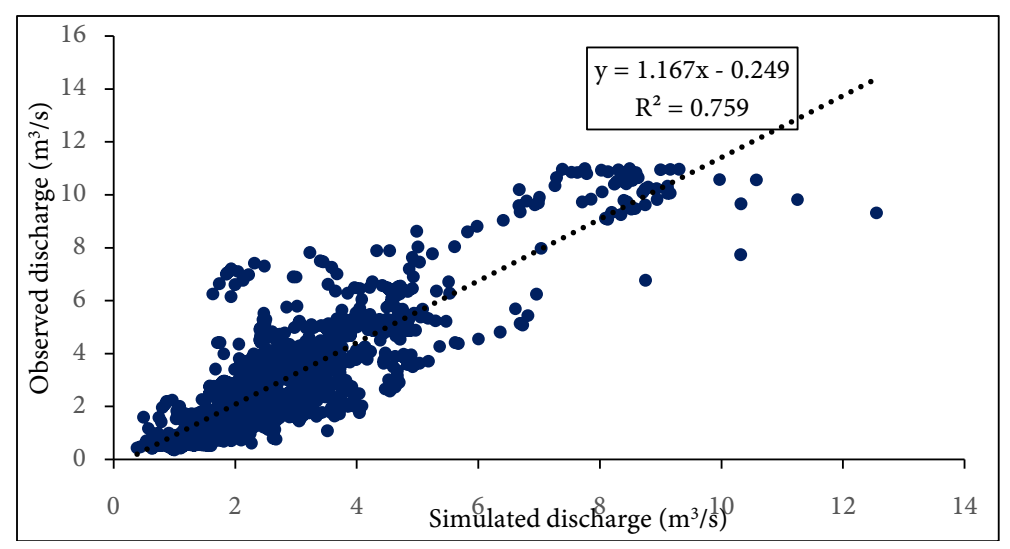

Figure 5. Scatter plot of observed and simulated discharge for the calibration period (1997-2002). 


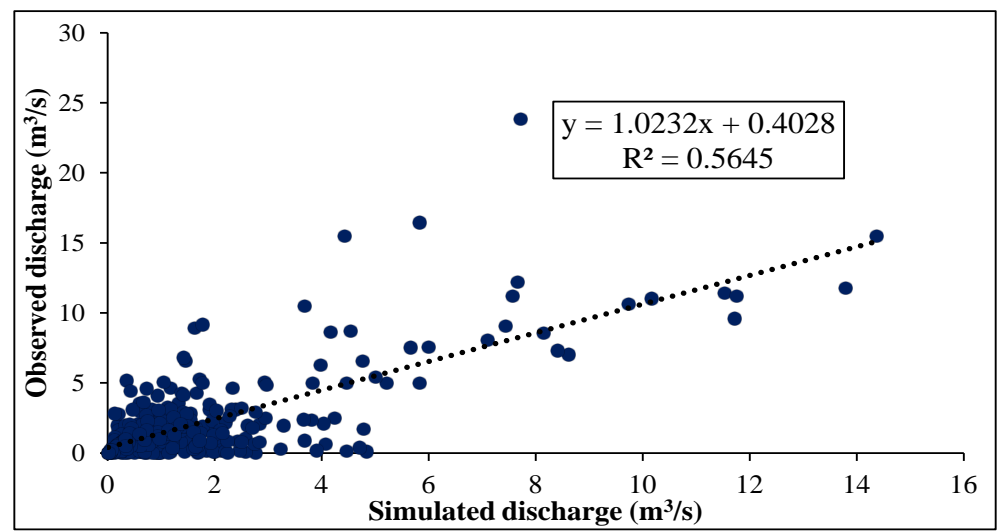

Figure 6. Scatter plot of observed and simulated discharge for the validation period (2004-2007).

Table 5. Daily time step SWAT calibration and validation statistics.

\begin{tabular}{ccccc}
\hline \multirow{2}{*}{ Stage of model } & \multicolumn{4}{c}{ Evaluated statistics } \\
\cline { 2 - 5 } & $R^{2}$ & $N S E$ & $R S R$ & $P B I A S(\%)$ \\
\hline Calibration (1997-2002) & 0.759 & 0.737 & 0.513 & 7.511 \\
Validation (2004-2007) & 0.565 & 0.540 & 0.678 & 22.584 \\
\hline
\end{tabular}

used as there were many missing days. The results also showed that, the model slightly underestimated flow during both the calibration and validation period as indicated by PBIAS values of approximately $8 \%$ and $23 \%$, respectively. According to Moriasi et al. [40], a PBIAS greater than zero is an indication that the model underestimated flow. During the calibration period (1997 to 2002), the observed and simulated mean daily flows were $3.1 \mathrm{~m}^{3} / \mathrm{s}$ and $2.91 \mathrm{~m}^{3} / \mathrm{s}$, respectively, while during the validation stage (20042007), the observed and simulated mean daily flows were $1.94 \mathrm{~m}^{3} / \mathrm{s}$ and $1.50 \mathrm{~m}^{3} / \mathrm{s}$, respectively.

Also, the underestimations could be attributed to uncertainties that exist in the catchment such as the wetland processes, quality of input data and wastewater discharge from point sources which could not be accounted for during the simulation. These plausible reasons including the limitations of using the SCS curve number (CN2) to compute estimate water budget componentshave also been noted by Abbaspour et al. [32] [48] and Betrie et al. [37] to be the cause of over and under prediction of flow. This observation agrees with that of Mutenyo et al. [43] and Qiu et al. [47] who recorded an underestimated streamflow discharge by the SWAT model. However, Qiu et al. [47] suggested that underestimation or overestimation [37] of streamflow discharge by the SWAT model is partly due to the use of curve number,which cannot give accurate prediction of runoff for days with several storms. Mutenyo et al. [43] attributed inaccurate simulation of streamflow discharge by the SWAT model to insufficient rain data. It is obvious that, if all these uncertainties are minimised, a well calibrated SWAT model can efficiently predict flow in the catchment for any management purpose.

\subsection{Impact of Land Use and Cover Change in the Murchison Bay Catchment}

To evaluate the effects of land use and cover change, the SWAT model calibrated and 
validated for streamflow discharge was used to simulate different land use and cover scenarios on runoff and sediment yield. Land use covers at two different years thus 1995 and 2003 were used as input variables in the SWAT model in order to compare output as a result of their differences in land covers. The simulated results of surface runoff and sediment yield in the catchment of the Murchison Bay under different land use and land cover scenarios using the SWAT model are shown in Table 6. The results showed an increase in runoff and average upland sediment yield, from the catchment except maximum upland sediment yield which reduced very slightly between the two periods. Surface runoff increased from $101 \mathrm{~mm} / \mathrm{yr}$ in 1995 to $128 \mathrm{~mm} / \mathrm{yr}$ in 2003 representing $26.7 \%$. This is attributed to the drastic land cover changes that occurred in the catchment. It highlights the effect of changes in land use and cover on hydrology in the catchment. Within the period, there was a sharp decline of forestland from $31.15 \%$ in 1995 to $13.91 \%$ while built-up land shot from $26.53 \%$ to $39.09 \%$.

The observation agrees with the assertion by Nie et al. [24] and Tang et al. [49] that, an increase in urban set-up increases impervious surfaces and declining forest lands, which accelerates surface runoff. Similarly, [50] reported that an increase in annual surface runoff increased when forest lands were converted to urban areas and decreased during when forestland gained a significant expansion. Maalim et al. [51] also made similar observation, areas dominated by urban development has higher runoff and lower runoff in forested areas. On the other hand, different studies [14] [44] [52] have reported that an expansion in forestland and grasslands lead to a decrease in runoff. Although, there is general agreement among researchers that changes in streamflow is due to different types of forestry activities, such as afforestation that may lead to lower runoff generation, others suggest the amount of precipitation [44] [52] and climate change [53] partly play a role. The increase in built-up land within the period might have possibly created impervious layers which reduced infiltration and percolation of water to the shallow aquifers that caused surface runoff to increase. According to Diyer et al. [54], when industrial or urban development takes place, the new land use changes how water is transported and stored. The combination of constraints connected to compacted lands and impervious surfaces such as parking lots, roads, sidewalks, and roofs leads to reduced infiltration. This causes, for instance, reduced water quality, increased volume and velocity of runoff, increased occurrence and severity of floods, and loss of storage capacity and runoff water in natural vegetation.

Surface Rrunoff is the carrier of all other components such as sediment, nutrient, pesticides, bacteria, agricultural waste, heavy metals, industrial solid and liquid waste that undesirably affects water quality. As surface runoff increases, it is evident that all the aforementioned components will correspondingly increase depending on the activities

Table 6. Estimated runoff and sediment under different land use and covers.

\begin{tabular}{cccc}
\hline Component & \multicolumn{2}{c}{ Land use/cover scenario } & \% change \\
\cline { 2 - 4 } & 1995 & 2003 & \\
\hline Surface runoff $(\mathrm{mm} / \mathrm{yr})$ & 101 & 128 & 26.73 \\
Maximum upland sediment yield (tons/ha/yr) & 26.54 & 26.40 & -0.53 \\
Average upland sediment yield (tons/ha/yr) & 5.22 & 6.29 & 20.50 \\
\hline
\end{tabular}


taking place in the catchment. However, the simulated results showed there was not much change in upland sediment yield over the period with increasing runoff. Upland sediment yield rather reduced by at least $0.50 \%$ between the two periods. This could still be attributed to the dynamics of land cover that happened at that time. Nevertheless, average upland sediment yield was about $20.50 \%$ higher in 2003 than that of 1995. This means that, some sub-basins within the catchment might have been exposed to massive degradation such as construction works and intensive agricultural activities than other sub-basins which resulted in higher sediment yield as runoff increased.

At a rate of 26.54 tons/ha/yr and 26.40 tons/ha/yr which translates to about 108,557 tons/yr and 107,984 tons/yr respectively, the sediment yield estimated in the catchment is greater than the results reported by Kimwaga et al. [55]. In the Simiyu catchment of the Lake Victoria basin, which is much larger than the Murchison Bay catchment, [55] reported a modelled estimate of sediment yield of 98,467 tons/yr though the actual measured sediment yield was $2,075,144$ tons/yr. The discrepancy was attributed to the data used to run the model.

The average estimates of sediment yield from upland and runoff from the landscape as well as possible mass loadings from point sources in the Murchison Bay catchment is a clear indication of the deterioration level of water quality that ends up into the Lake Victoria. This is supported by [10] situation analysis report that increasing human population and all their associated economic and social activities have accelerated the rate of delivery of nutrients and caused eutrophication in Lake Victoria. However, it is anticipated that the values of the components estimated have changed tremendously as the catchment is now condensed with more settlements, industries and increased in population of Kampala city from 1.2 million in 2002 to 1.5 million in 2014 [28].

\section{Conclusion and Recommendation}

In this study, the SWAT model was used to assess the impact of land use and cover change on the Murchison Bay catchment. The calibrated SWAT model satisfactorily simulated streamflow with satisfactory statistical measures results. Average runoff and sediment yield loss from the catchment was also estimated. The estimations showed that because of rapid changes that occurred over the past, it has led to an increased runoff and average upland yield by $26.73 \%$ and $20.50 \%$ respectively while maximum upland sediment yield relatively reduced by $0.50 \%$ because of increasing impervious surfaces in the catchment. The effects of increasing surface runoff are that, water quality and crop yield in addition to aquatic life are negatively affected as it transports nutrients and other pollutants. This may also explain severe and frequent flooding, which has been experienced in the catchment lately. Therefore, pragmatic strategies for sustainable water and environmental resources in the catchment should be developed for sustainable water and environmental resources in the catchment. This is the first time the SWAT model has been used in the Murchison Bay catchment. The results showed that, if all uncertainties are minimised, a well calibrated SWAT model can generate reasonable hydrologic simulation results in relation to land use, which is useful to water and environmental resources managers and policy and decision makers. 


\section{Acknowledgements}

The authors wish to thank the METEGA Project and RUFORUM for their financial support.

\section{References}

[1] Ndulue, E.L., Mbajiorgu, C.C., Ugwu, S.N., Ogwo, V. and Ogbu, K.N. (2015) Assessment of Land Use/Cover Impacts on Runoff and Sediment Yield Using Hydrologic Models : A Review. Journal of Ecology and the Natural Environment, 7, 46-55. https://doi.org/10.5897/JENE2014.0482

[2] Ellis, E. (2013) Land-Use and Land-Cover Change. In: Pontius, R., Eds., The Encyclopedia of Earth.

[3] Ayivor, J.S. and Gordon, C. (2012) Impact of Land Use on River Systems in Ghana. West African Journal of Applied Ecology, 20, 83-95.

[4] Kashaigili, J.J. (2008) Impacts of Land-Use and Land-Cover Changes on Flow Regimes of the Usangu Wetland and the Great Ruaha River, Tanzania. Physics and Chemistry of the Earth, 33, 640-647. https://doi.org/10.1016/j.pce.2008.06.014

[5] Tufa, D.F., Abbulu, Y. and Srinivasarao, G.V.R. (2014) Watershed Hydrological Response to Changes in Land Use/Land Covers Patterns of River Basin: A Review. International Journal of Civil, Structural, Environmental and Infrastructure Engineering Research and Development (IJCSEIERD), 4, 157-170.

[6] Matagi, S.V. (2002) Some Issues of Environmental Concern in Kampala, the Capital City of Uganda. Environmental Monitoring and Assessment, 77, 121-138.

https://doi.org/10.1023/A:1015860820467

[7] Akurut, M., Willems, P. and Niwagaba, C.B. (2014) Assessing the Influence of Lake Victoria Flux on the Inner Murchison Bay Water Quality. WIT Transactions on Ecology and the Environment, 182, 51-62. https://doi.org/10.2495/WP140051

[8] Banadda, E.N., Kansiime, F., Kigobe, M., Kizza, M. and Nhapi, I. (2009) Land Use-Based Nonpoint Source Pollution: A Threat to Water Quality in Murchison Bay, Uganda. Water Policy, 11, 94-105. https://doi.org/10.2166/wp.2009.106

[9] Haande, S., Rohrlack, T., Semyalo, R.P., Brettum, P., Edvardsen, B., Lyche-Solheim, A., Sørensen, K. and Larsson, P. (2011) Phytoplankton Dynamics and Cyanobacterial Dominance in Murchison Bay of Lake Victoria (Uganda) in Relation to Environmental Conditions. Limnologica-Ecology and Management of Inland Waters, 41, 20-29. https://doi.org/10.1016/j.limno.2010.04.001

[10] JTR (2015) Development of a Pollution Management Strategy to Improve Long Term Water Quality Status in the Inner Murchison Bay, Lake Victoria \& Initiate Implementation of Its Initiatives. Joint Technical Review Situation Analysis Report, 1-22.

[11] Mbabazi, J., Kwetegyeka, J., Ntale, M. and Wasswa, J. (2010) Ineffectiveness of Nakivubo Wetland in Filtering Out Heavy Metals from Untreated Kampala Urban Effluent Prior to Discharge into Lake Victoria, Uganda. African Journal of Agricultural Research, 5, 34313439.

[12] MWE (2013) Framework and Guidelines for Water Source Protection. Framework for Water Source Protection, Ministry of Water and Environment, Vol. 1, 1-75.

[13] Pandav, B., Choudhury, B.C. and Patnaik, S.K. (2002) Information Sheet on Ramsar Wetlands-Bhitarkanika Mangroves. Ramsar, 1-8.

[14] Li, Z., Deng, X., Wu, F. and Hasan, S.S. (2015) Scenario Analysis for Water Resources in Response to Land Use Change in the Middle and Upper Reaches of the Heihe River Basin. Sustainability (Switzerland), 7, 3086-3108. 
[15] Ahmad, H., Jamieson, R., Havard, P., Madani, A. and Zaman, Q. (2009) Evaluation of SWAT for a Small Watershed in Eastern Canada. 337-343.

[16] Abbaspour, K.C., Vejdani, M., Haghighat, S. and Yang, J. (2007) SWAT-CUP Calibration and Uncertainty Programs for SWAT. In: Oxley, L. and Kulasiri, D. Eds., MODSIM 2007 International Congress on Modelling and Simulation, Modelling and Simulation Society of Australia and New Zealand, 1596-1602.

[17] Moriasi, D.N., et al. (2015) Hydrologic and Water Quality Models: Key Calibration and Validation Topics. Transactions of the ASABE, 58, 1609-1618.

https://doi.org/10.13031/trans.58.11075

[18] Van Liew, M.W., Arnold, J.G. and Bosch, D.D. (2005) Problems and Potential of Autocalibrating a Hydrologic Model. Transactions of the ASABE, 48, 1025-1040.

[19] Arnold, J.G., et al. (2012) SWAT: Model Use, Calibration, and Validation. American Society of Agricultural and Biological Engineer, 55, 1491-1508.

[20] Gassman, P.W., Reyes, M.R., Green, C.H. and Arnold, J.G. (2007) The Soil and Water Assessment Tool: Historical Development, Applications, and Future Research Direction. American Society of Agricultural and Biological Engineers, 50, 1211-1250.

[21] Neitsch, S.L., Arnold, J.G., Kiniry, J.R. and Williams, J.R. (2011) Soil \& Water Assessment Tool Theoretical Documentation Version 2009. Technical Report, Texas Water Resources Institute, College Station, 1-647.

[22] Gassman, P.W. and Yingkuan, W. (2015) IJABE SWAT Special Issue : Innovative Modeling Solutions for Water Resource Problems. International Journal of Agricultural and Biological Engineering, 8, 1-8.

[23] Arnold, J.G., Kiniry, J.R., Srinivasan, R., Williams, J.R., Haney, E.B. and Neitsch, S.L. (2012) Soil \& Water Assessment Tool: Input/Output Documentation. Version 2012. TR-439, Texas Water Resources Institute, College Station, 1-650.

[24] Nie, W., Yuan, Y., Kepner, W., Nash, M.S., Jackson, M. and Erickson, C. (2011) Assessing Impacts of Landuse and Landcover Changes on Hydrology for the Upper San Pedro Watershed. Journal of Hydrology, 407, 105-114. https://doi.org/10.1016/j.jhydrol.2011.07.012

[25] Kansiime, F. and Nalubega, M. (1999) Wastewater Treatment by a Natural Wetland: The Nakivubo Swamp, Uganda. PhD Thesis, Wageningen Agricultural University, Netheriand.

[26] Ghoraba, S.M. (2015) Hydrological Modeling of the Simly Dam Watershed (Pakistan) Using GIS and SWAT Model. Alexandria Engineering Journal, 54, 583-594. https://doi.org/10.1016/j.aej.2015.05.018

[27] Anderson, J.R., Hardy, E.E., Roach, J.T. and Witmer, R.E. (1976) A Land Use and Land Cover Classification System for Use with Remote Sensor Data. A Revision of the Land Use Classification System as Presented in US Geological Survey Circular 671, 1-41.

[28] UBOS (2014) National Population and Housing Census. Uganda Bureau of Statistics, Kampala, 1-73.

[29] FAO-UNESCO (2003) The Digital Soil Map of the World, Version 3.6. Land and Water Development Division, FAO, Rome.

[30] FAO-UNESCO (1977) FAO-UNESCO Soil Map of the World, 1:5000000: Africa. United Nations Educational, Scientific and Cultural Organization, Paris, 346.

[31] Winchell, M., Srinivasan, R., Di Luzio, M. and Arnold, J.G. (2013) Arcswat Interface for SWAT2012: User's Guide. Blackland Research Center, Texas AgriLife Research, College Station, 1-464.

[32] Abbaspour, K.C., et al. (2007) Modelling Hydrology and Water Quality in the Pre-Alpine/Alpine Thur Watershed Using SWAT. Journal of Hydrology, 333, 413-430.

https://doi.org/10.1016/j.jhydrol.2006.09.014 
[33] Das, S.K., Ng, A.W.M. and Perera, B.J.C. (2013) Sensitivity Analysis of SWAT Model in the Yarra River Catchment. 20th International Congress on Modelling and Simulation, Adelaide, 1-6 December 2013, 1666-1672.

[34] Neitsch, S.L., Arnold, J.G., Kiniry, J.R., Srinivasan, R. and Williams, J.R. (2002) Soil and Water Assessment Tool User's Manual, Version 2000. Texas TWRI Report TR-192, Texas Water Resources Institute, College Station, 1-412.

[35] Van Griensven, A., Meixner, T., Grunwald, S., Bishop, T., Diluzio, M. and Srinivasan, R. (2006) A Global Sensitivity Analysis Tool for the Parameters of Multi-Variable Catchment Models. Journal of Hydrology, 324, 10-23. https://doi.org/10.1016/j.jhydrol.2005.09.008

[36] Abbaspour, K.C. (2015) SWAT-Calibration and Uncertainty Programs (CUP) - A User Manual. Swiss Federal Institute of Aquatic Science and Technology, Eawag, Duebendorf, 1100.

[37] Betrie, G.D., Mohamed, Y.A., Griensven, A. and Srinivasan, R. (2011) Sediment Management Modelling in the Blue Nile Basin Using SWAT Model. Hydrology and Earth System Sciences, 15, 807-818. https://doi.org/10.5194/hess-15-807-2011

[38] Engel, B., Storm, D., White, M., Arnold, J. and Arabi, M. (2007) A Hydrologic/Water Quality Model Application Protocol. Journal of the American Water Resources Association, 43, 1223-1236. https://doi.org/10.1111/j.1752-1688.2007.00105.x

[39] Costa, D., Avelino, R., Sára, S., Thomazini, L., Aurélio, M. and Caiado, C. (2015) Application of the SWAT Hydrologic Model to a Tropical Watershed at Brazil. Catena, 125, 206213. https://doi.org/10.1016/j.catena.2014.10.032

[40] Moriasi, D.N., Arnold, J.G., van Liew, M.W., Binger, R.L., Harmel, R.D. and Veith, T.L. (2007) Model Evaluation Guidelines for Systematic Quantification of Accuracy in Watershed Simulations. Transactions of the ASABE, 50, 885-900.

https://doi.org/10.13031/2013.23153

[41] Getachew, H.E. and Melesse, A.M. (2012) The Impact of Land Use Change on the Hydrology of the Angereb Watershed, Ethiopia. International Journal of Water Sciences, 1, 1-7.

[42] Gyamfi, C., Ndambuki, J.M. and Salim, R.W. (2016) Application of SWAT Model to the Olifants Basin: Calibration, Validation and Uncertainty Analysis. Journal of Water Resource and Protection, 8, 397-410. https://doi.org/10.4236/jwarp.2016.83033

[43] Mutenyo, I., Nejadhashemi, A.P., Woznicki, S.A. and Giri, S. (2013) Evaluation of SWAT Performance on a Mountainous Watershed in Tropical Africa. Hydrology Current Research, $\mathrm{S14}, 1-7$.

[44] Zuo, D., Xu, Z., Yao, W., Jin, S., Xiao, P. and Ran, D. (2016) Assessing the Effects of Changes in Land Use and Climate on Runoff and Sediment Yields from a Watershed in the Loess Plateau of China. Science of the Total Environment, 544, 238-250. https://doi.org/10.1016/j.scitotenv.2015.11.060

[45] Asres, M.T. and Awulachew, S.B. (2011) SWAT Based Runoff and Sediment Yield Modelling: A Case Study of the Gumera Watershed in the Blue Nile Basin. Ecohydrology and Hydrobiology, 10, 191-200. https://doi.org/10.2478/v10104-011-0020-9

[46] Gamvroudis, C., Nikolaidis, N.P., Tzoraki, O., Papadoulakis, V. and Karalemas, N. (2015) Water and Sediment Transport Modeling of a Large Temporary River Basin in Greece. Science of the Total Environment, 508, 354-365. https://doi.org/10.1016/j.scitotenv.2014.12.005

[47] Qiu, L.J., Zheng, F.L. and Yin, R.S. (2012) SWAT-Based Runoff and Sediment Simulation in a Small Watershed, the Loessial Hilly-Gullied Region of China: Capabilities and Challenges. International Journal of Sediment Research, 27, 226-234. https://doi.org/10.1016/S1001-6279(12)60030-4

[48] Abbaspour, K.C., Rouholahnejad, E., Vaghefi, S., Srinivasan, R., Yang, H. and Kløve, B. 
(2015) A Continental-Scale Hydrology and Water Quality Model for Europe: Calibration and Uncertainty of a High-Resolution Large-Scale SWAT Model. Journal of Hydrology, 524, 733-752. https://doi.org/10.1016/j.jhydrol.2015.03.027

[49] Tang, Z., Engel, B.A., Pijanowski, B.C. and Lim, K.J. (2005) Forecasting Land Use Change and Its Environmental Impact at a Watershed Scale. Journal of Environmental Management, 76, 35-45. https://doi.org/10.1016/j.jenvman.2005.01.006

[50] Ngo, T.S., Nguyen, D.B. and Rajendra, P.S. (2015) Effect of Land Use Change on Runoff and Sediment Yield in Da River Basin of Hoa Binh Province, Northwest Vietnam. Journal of Mountain Science, 12, 1051-1064. https://doi.org/10.1007/s11629-013-2925-9

[51] Maalim, F.K., Melesse, A.M., Belmont, P. and Gran, K.B. (2013) Modeling the Impact of Land Use Changes on Runoff and Sediment Yield in the Le Sueur Watershed, Minnesota Using GeoWEPP. Catena, 107, 35-45. https://doi.org/10.1016/j.catena.2013.03.004

[52] Silveira, L. and Alonso, J. (2008) Runoff Modifications Due to the Conversion of Natural Grasslands to Forests in a Large Basin in Uruguay. Hydrological Processes, 23, 320-329. https://doi.org/10.1002/hyp.7156

[53] Yan, B., Fang, N.F., Zhang, P.C. and Shi, Z.H. (2013) Impacts of Land Use Change on Watershed Streamflow and Sediment Yield: An Assessment Using Hydrologic Modelling and Partial Least Squares Regression. Journal of Hydrology, 484, 26-37. https://doi.org/10.1016/j.jhydrol.2013.01.008

[54] Diyer, M., Namrani, H. and Elkadiri, A. (2013) Land Use and Land Management Practices in Environmental Perspective. 1-81.

[55] Kimwaga, R.J., Bukirwa, F., Banadda, N., Wali, U.G., Nhapi, I. and Mashauri, D.A. (2012) Modelling the Impact of Land Use Changes on Sediment Loading into Lake Victoria Using SWAT Model: A Case of Simiyu Catchment Tanzania. The Open Environmental Engineering Journal, 5, 66-76. https://doi.org/10.2174/1874829501205010066

Submit or recommend next manuscript to SCIRP and we will provide best service for you:

Accepting pre-submission inquiries through Email, Facebook, LinkedIn, Twitter, etc. A wide selection of journals (inclusive of 9 subjects, more than 200 journals)

Providing 24-hour high-quality service

User-friendly online submission system

Fair and swift peer-review system

Efficient typesetting and proofreading procedure

Display of the result of downloads and visits, as well as the number of cited articles

Maximum dissemination of your research work

Submit your manuscript at: http://papersubmission.scirp.org/

Or contact cweee@scirp.org 